\title{
The Placenta of Physcomitrium patens: Transfer Cell Wall Polymers Compared across the Three Bryophyte Groups
}

\author{
Jason S. Henry ${ }^{1, *}$ and Karen S. Renzaglia ${ }^{2}$ \\ 1 Department of Biology, Southeast Missouri State University, Cape Girardeau, MO 63701, USA \\ 2 Department of Plant Biology, Southern Illinois University Carbondale, Carbondale, IL 62901, USA; \\ renzaglia@siu.edu \\ * Correspondence: jhenry@semo.edu
}

Citation: Henry, J.S.; Renzaglia, K.S. The Placenta of Physcomitrium patens: Transfer Cell Wall Polymers Compared across the Three Bryophyte Groups. Diversity 2021, 13, 378. https://doi.org/10.3390/ d13080378

Academic Editors: Eric Buffetaut and Jakub Sawicki

Received: 20 July 2021

Accepted: 6 August 2021

Published: 15 August 2021

Publisher's Note: MDPI stays neutral with regard to jurisdictional claims in published maps and institutional affiliations.

Copyright: (c) 2021 by the authors. Licensee MDPI, Basel, Switzerland. This article is an open access article distributed under the terms and conditions of the Creative Commons Attribution (CC BY) license (https:/ / creativecommons.org/licenses/by/ $4.0 /)$.

\begin{abstract}
Following similar studies of cell wall constituents in the placenta of Phaeoceros and Marchantia, we conducted immunogold labeling TEM studies of Physcomitrium patens to determine the composition of cell wall polymers in transfer cells on both sides of the placenta. Sixteen monoclonal antibodies were used to localize cell wall epitopes in the basal walls and wall ingrowths in this moss. In general, placental transfer cell walls of $P$. patens contained fewer pectins and far fewer arabinogalactan proteins AGPs than those of the hornwort and liverwort. P. patens also lacked the differential labeling that is pronounced between generations in the other bryophytes. In contrast, transfer cell walls on either side of the placenta of P. patens were relatively similar in composition, with slight variation in homogalacturonan HG pectins. Compositional similarities between wall ingrowths and primary cell walls in P. patens suggest that wall ingrowths may simply be extensions of the primary cell wall. Considerable variability in occurrence, abundance, and types of polymers among the three bryophytes and between the two generations suggested that similarity in function and morphology of cell walls does not require a common cell wall composition. We propose that the specific developmental and life history traits of these plants may provide even more important clues in understanding the basis for these differences. This study significantly builds on our knowledge of cell wall composition in bryophytes in general and in transfer cells across plants.
\end{abstract}

Keywords: arabinogalactan protein; cell wall; pectin; hemicellulose; transfer cell; wall ingrowth; Physcomitrium patens

\section{Introduction}

Because the sporophyte of bryophytes is matrotrophic, the placenta is the principal site for nutrient uptake that drives the production and dispersal of spores [1,2]. In this intergenerational zone, specialized cells facilitate an intensified unidirectional flow of solutes to the sporophyte that is dependent on the persistent gametophyte [3,4]. Transfer cells characterized by localized cell wall ingrowths are common in both generations in bryophytes, but they are not universal, as they may be absent or restricted to either side of the placental junction $[1,5]$. In transfer cells, wall ingrowths form an elaborate network or labyrinths that vastly increases the surface area of the plasmalemma, which enhances membrane-mediated nutrient transport in strategically located and specialized cell-cell junctions $[3,4,6]$. Wall ingrowths create a more extensive and presumably specialized apoplast and a cell wall/plasma membrane complex that is polarized and produces a directional apoplastic/symplastic exchange of solutes [7]. In addition to bryophyte placentae, transfer cells are common in tracheophytes in areas of high solute transport, such as in phloem, vascular parenchyma [8], angiosperm embryos [7,9-12], secretory glands [13], and root nodules $[14,15]$. In the placenta of mosses, carbon in the form of sucrose moves within the gametophyte symplastically and is actively loaded from the apoplast into the foot of the sporophyte [16,17]. In Physcomitrium patens, as in most mosses and many liverworts, transfer cells with cell wall ingrowths are located on both sides of the placenta [1]. Cell 
wall ingrowths and an abundance of mitochondria and plastids reflect the energy-intensive process of transferring nutrients across the extensive surface area and the dependence on proximally located sources of ATP [16]. Although the transport pathway at the placental interface of $P$. patens is beginning to be understood, little is known about the composition of wall polymers in these unique cells in mosses.

This study aims to fill in gaps in our knowledge concerning the polymer composition in bryophytes by examining the placenta of P. patens. Similar studies of placental cell walls in the liverwort Marchantia polymorpha [18] and two species of the hornwort Phaeoceros [5] allowed for comparisons across all three bryophyte groups and across the two generations. Phaeoceros has transfer cells restricted to the gametophyte side, while M. polymorpha is similar to P. patens in the occurrence of transfer cells on both sides of the placenta. The placentae in Phaeoceros and M. polymorpha have AGPs not found in other parts of the plant that support signaling functions in this region of transport. In Marchantia, cell wall ingrowths are rich in pectins, but arabinogalactan proteins (AGPs) and xyloglucans are abundant only on the sporophyte side. In Phaeoceros, pectins are diverse and abundant, while AGPs are restricted to the placenta region only.

Two fundamental questions were addressed in this study: (1) How do cell wall constituents differ in the two generations of the bryophyte placenta within $P$. patens? and (2) What differences are there in composition between these cell walls and those in transfer cells of other plant groups? This comparative approach provides insights into the diversity and evolution in cell wall composition of transfer cells among the three bryophyte groups and across land plants.

\section{Materials and Methods}

\subsection{Gametophyte Culture}

Mature capsules were sterilized using a $10 \%$ bleach solution. After three rinses in autoclaved distilled water, capsules were ruptured, and the released spores were sown on agar with Parker Thompson nutrient medium. Following gametophore development, plants were transferred to vermiculite and kept in the growth chamber until antheridia and archegonia were present. Cultures were then flooded to facilitate fertilization. Plants with green capsules were harvested and processed as follows.

\subsection{Preparation for Transmission Electron Microscopy}

For TEM observation, plants were processed according to the standard fixation protocol outlined in Renzaglia et al. 2017 [19]. Excised potions of gametophytic tissue with embedded sporophytes were fixed in $2.5 \%$ glutaraldehyde in 0.05 M Sorenson's buffer ( $\mathrm{pH}$ 7.2) for one hour at room temperature and overnight at $4{ }^{\circ} \mathrm{C}$. Following 3 rinses in the same buffer for 15 min each, plants were post-fixed in $2 \%$ buffered osmium tetroxide for $15 \mathrm{~min}$ and rinsed in autoclaved, distilled water. The specimens were dehydrated in progressively higher ethanol to water concentrations and rinsed twice in $100 \%$ ethanol. Infiltration was achieved by progressively increasing the concentration of LR White resin diluted with ethanol from $25 \%-50 \%-75 \%$, and finally $100 \%$. Specimens were exchanged three times in $100 \%$ LR White resin, placed in fresh resin in gel capsules, and cured in an oven at $60{ }^{\circ} \mathrm{C}$ for $48 \mathrm{~h}$. The samples were sectioned on an ultramicrotome until the placenta was located. Either thin sections (90-100 nm) were collected on 200 mesh nickel grids for immuno-labeling, or thick sections (800 to $1500 \mathrm{~nm}$ ) were collected on glass slides and stained with toluidine blue for light microscopy. Sporophytes with developing spores were selected and examined.

\subsection{Immunogold Labeling}

The 16 monoclonal antibodies (MAbs) in Table 1 were used to probe cell wall polymers in the placental cell walls of Physcomitrium patens. Specimens were processed as follows and outlined in Lopez et al. 2017 [20]. Grids were placed in BSA/PBS overnight at $14{ }^{\circ} \mathrm{C}$, and then overnight on a primary antibody specific to the desired wall epitope. Samples 
were then rinsed four times in $0.05 \mathrm{M}$ BSA/PBS for 4 min each. Samples were incubated overnight at $4^{\circ} \mathrm{C}$ in a secondary antibody with a $10 \mathrm{~nm}$ gold tag that attached to the primary antibody. Samples were then rinsed in PBS four times at 4 min each and rinsed with a jet of sterile $\mathrm{H}_{2} \mathrm{O}$. The primary antibody, secondary antibody, and gold tag complex attached to the desired wall epitope, making the targeted wall polymer visible as a black dot in the TEM at $7000 \times$ magnification or higher. Control grids were prepared by excluding the primary antibodies.

Table 1. Primary monoclonal antibodies (MAbs) used to immunogold label carbohydrates and arabinogalactan proteins in placental cell walls of Physcomitrium patens.

\begin{tabular}{ccc}
\hline Antibody & Antigen(s)/Epitope & Reference/Source \\
\hline JIM7 & Homogalacturonan/Methyl-esterified & {$[21]$} \\
JIM5 & Homogalacturonan/Unesterified & {$[22]$} \\
LM19 & Homogalacturonan/Unesterified & {$[23]$} \\
LM20 & Homogalacturonan/Methyl-esterified & {$[23]$} \\
LM5 & Galactan, rhamnogalacturonan-I/(1-4)- $\beta$-D-galactan & {$[24]$} \\
LM13 & Arabinan, rhamnogalacturonan-I/(1-5)- $\alpha$-L-arabinan & {$[25]$} \\
LM15 & (linear) & {$[26]$} \\
LM25 & XXXG motif of xyloglucan & {$[27]$} \\
LM21 & Galactoxylated xyloglucans & {$[28]$} \\
LM28 & Mannan/ $\beta$-(1,4)-manno-oligosaccharide & {$[29]$} \\
JIM13 & Grabinogalactan protein (AGP)/ $\beta$-D-GlcA-(1,3)- $\alpha$-D-GalpA- & {$[30]$} \\
& (1,2)-L-Rha(glucuronicacid-galacturonicacid-rhamnose) & \\
LM6 & Arabinan, rhamnogalacturonan-I/(1-5)- $\alpha$-L-arabinan(also & {$[31]$} \\
JIM8 & labels AGP) & {$[32]$} \\
LM2 & Arabinogalactan protein (AGP) $\beta-D-G l c A$ (glucuronic acid) & {$[33]$} \\
Anticallose & Callose/(1,3)- $\beta$-linked penta-to-hexa-glucan & {$[34]$} \\
JIM12 & Extensin & {$[35]$} \\
\hline
\end{tabular}

Samples were observed before and after post-staining using lead citrate and uranyl acetate. These stains allowed for better contrast, but can obscure the immunogold labels in the TEM. Samples were viewed and digital micrographs were collected using a Hitachi H7650.

\subsection{Scoring Label Intensity}

Micrographs were opened in the PhotoScapeX editing app. Three counting frames sized at $100 \times 100$ pixels were then randomly placed onto the wall in the image. The labels within each frame were then counted and recorded. This process was repeated three times per image, and for each MAb, 10 images were counted. The average of all counts was then calculated. An average of 1 to 4 labels per frame were assigned a single plus (+). If the average was 5 to 9 labels, two pluses $(++)$ were given. Any averages that were greater than 10 labels per frame received a triple plus $(+++)$. A few antibodies had scores $<1$ but $>0$, and were assigned a plus/minus $( \pm)$.

\section{Results}

The foot of $P$. patens is small, typically less than $500 \mu \mathrm{m}$ long, and six or seven cells in diameter (Figure 1a). A ring of gametophytic tissue (the vaginula), derived from the archegonium, surrounds the foot that is cylindrical and gradually tapers to a pointed tip where it penetrates the gametophore. The vaginula ensheaths the foot along most of its length. The foot is fully developed when the sporophyte capsule begins to expand, and sporogenous tissue is delimited (Figure 1a). At this stage, the capsule is emerging from beneath the calyptra, and stomata are developed. Transfer cells reach maturation and line both sides of the placenta by the time meiosis is completed, and persist throughout spore differentiation (Figure 1b,c). Cell wall ingrowths are generally more elaborate on the 
gametophyte side of the placenta compared with the foot side, and they are less abundant at the tip of the foot (Figure 1d,e and Figure 2a). Wall ingrowths in both gametophyte and sporophyte transfer cells contain a fibrous core (sporophyte side) or vesicular dense core (gametophyte side) and an irregular outer electron-lucent zone that is bordered by the plasmalemma (Figure 2a). Along the sides of the foot, the two generations make contact, and the intergenerational zone is obscured (Figure 1c,d and Figure 2a). At the foot tip, degenerating gametophyte cells leave a mucilaginous matrix (Figure 1e). Transfer cells of the foot are more isodiametric than those of the gametophyte, and they contain numerous small vacuoles and peripheral cytoplasm with numerous mitochondria, and elongated plastids with dense stroma, few membranes, and no starch (Figures $1 d$ and $2 b$ ). Gametophyte transfer cells contain dense cytoplasm with prominent rounded plastids that are rich in starch (Figure 1d,e and Figure 2c).

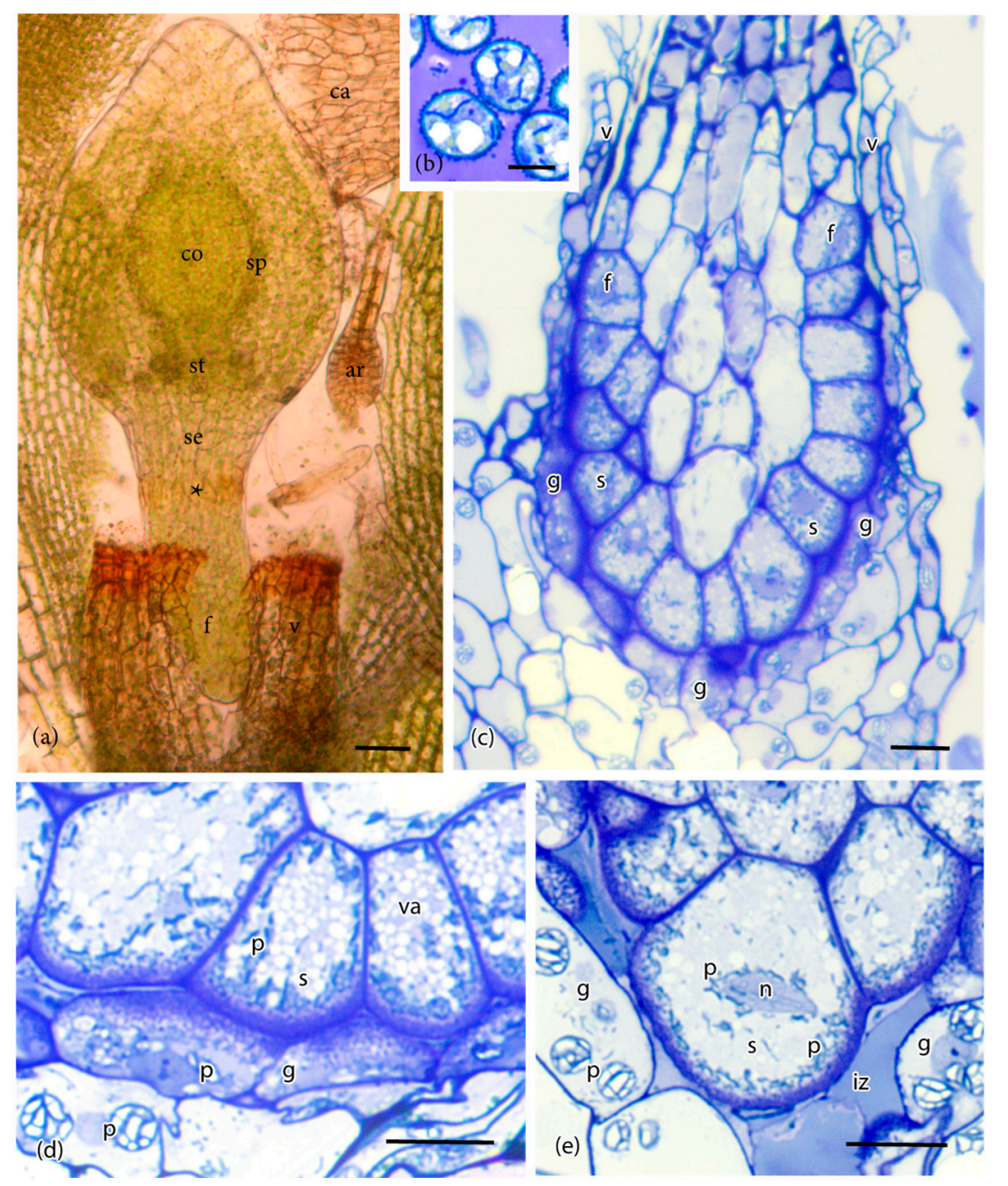

Figure 1. Anatomy of the sporophyte and placenta of Physcomitrium patens. (a) Developing sporophyte with expanding capsule containing a central columella (co), sporogenous layer (sp), and a zone of stomata (st) at the base. The seta (se) is short and continuous with the cylindrical foot (f), which tapers at the tip. The calyptra (ca) was dislodged from the capsule and the vaginula (v) disrupted in slide preparation to reveal the region where the foot and seta meet $\left.{ }^{*}\right)$. Note: Ar, unfertilized archegonium. (b) Spores in the capsule with mature placenta showing the stage of development examined in (c-e). (c) Longitudinal light microscope section of the sporophyte (s) embedded in the gametophyte ( $\mathrm{g}$ ) showing the cylindrical foot (f) at its upper limit and adjacent gametophyte transfer cells. The foot with peripheral transfer cells connects to the vaginula (v). (d) Along most of its length, the placenta consists of abutting sporophyte (s) and gametophyte (g) cells with extensive wall ingrowths. 
Sporophyte cells contain abundant small vacuoles (va) and dense plastids (p). Gametophyte cells contain rounded plastids (p) with starch grains. (e) At the tip of the foot, cell wall ingrowths are few, and an intergenerational zone (iz) is evident from the breakdown of gametophyte cells. Gametophyte (g) cells contain starch-filled plastids (p), and sporophyte (s) cells have numerous dense plastids (p) around the cell periphery and near the nuclei (n). Scale bars $=50 \mu \mathrm{m}(\mathbf{a}) ; 10 \mu \mathrm{m}(\mathbf{b}-\mathbf{e})$.

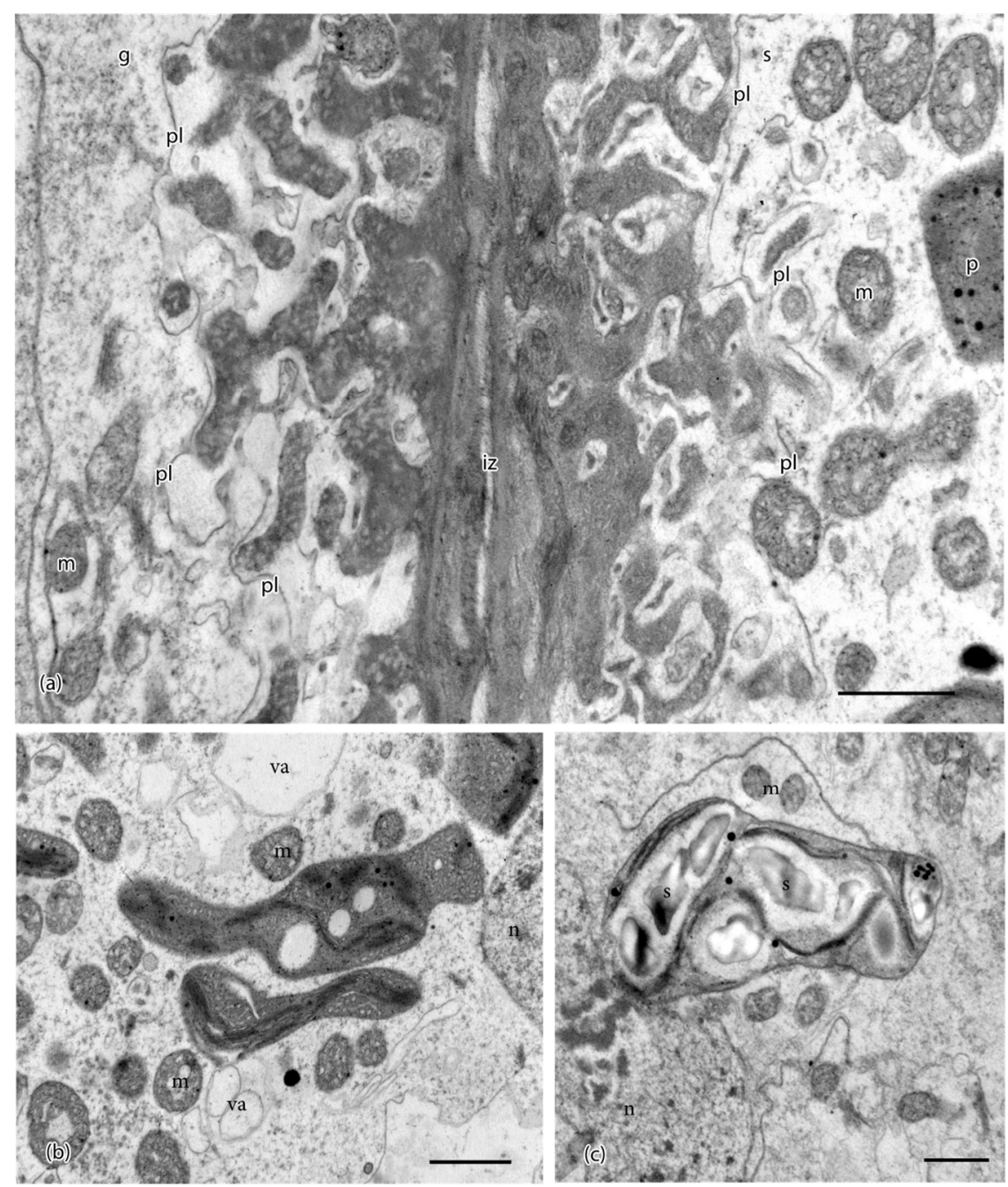

Figure 2. Ultrastructural details of placental cells taken in the TEM. (a) Transfer cells in gametophyte (g) and sporophyte (s) are separated by a narrow intergenerational zone (iz) and show elaborate cell wall labyrinths. An electron-lucent region is delimited by the plasmalemma (pl) and surrounds the dense inner core of cell wall ingrowths, which are more vesicular in the gametophyte. Mitochondria (m) and plastids (p) are located near wall ingrowths. (b) Plastids in sporophyte (s) cells are irregular in shape, dense, vesiculate, and contain few thylakoids. Mitochondria (m) and small vacuoles (va) are numerous in sporophyte cells. Note: $n$, nucleus. (c) Plastids in gametophyte (g) cells contain starch grains (s) surrounded by thylakoids. Note: $\mathrm{m}$, mitochondria; $\mathrm{n}$, nucleus. Scale bars $=0.1 \mu \mathrm{m}$.

Label intensities in the sporophyte and gametophyte cell walls for the 16 MAbs used in this study are summarized in Table 2. Three of the four MAbs for HG pectins localized epitopes of these pectins in the P. patens placenta (Figure 3). Labeling with JIM7 for methylesterified HG pectins was light in the gametophyte basal wall layer and wall ingrowths (Figure 3a). Moderate labeling for this MAb occurred in sporophyte transfer cell walls (Figure 3a). The JIM5 MAb that also targeted a de-esterified HG epitope showed light labeling in electron-dense regions in both the basal wall layer and cell wall ingrowths in both generations (Figure 3b,c). The LM19 MAb recognized de-esterified HG labels 
throughout the electron-dense portions of the cell wall ingrowths, as well as the basal wall, in both generations (Figure 3d,e). No labeling was observed for the LM20 MAb.

Table 2. Relative intensities of immunogold labeling for sporophyte and gametophyte placental cell walls in P. patens with 16 monoclonal primary antibodies.

\begin{tabular}{ccc}
\hline Primary Antibody & Sporophyte & Gametophyte \\
\hline JIM7 & ++ & + \\
JIM5 & + & + \\
LM19 & + & ++ \\
LM20 & - & \pm \\
LM5 & + & \pm \\
LM13 & \pm & \pm \\
LM15 & \pm & + \\
LM25 & \pm & + \\
LM21 & + & - \\
LM28 & - & \pm \\
JIM13 & \pm & + \\
LM6 & \pm & - \\
JIM8 & - & - \\
LM2 & - & + \\
Callose & + & - \\
JIM12 & - & \\
\hline
\end{tabular}

$\overline{\text { Note: }+++ \text {, very strong; }++ \text {, strong; +, weak; } \pm \text {, present; - , absent; }{ }^{*} \text { LM6 binds to arabinan residues in RG-I pectins }}$ and AGPs.

The presence of RG-I pectins was identified by two MAbs (Tables 1 and 2). The LM5 MAb lightly labeled the basal wall layer and wall ingrowths on the sporophyte side, and less so on the gametophyte side (Figure 3f). The LM13 MAb showed very light labeling in the basal cell wall and wall ingrowths in both generations (Figure 3g).

The LM15 hemicellulose MAb targeting xyloglucan sparsely labeled cell wall ingrowths in both generations (Figure 4a,b; Table 2). Galactoxylated xyloglucans, as localized with the LM25 MAb, were found in the basal wall and wall ingrowths in transfer cells in both generations, with fewer labels on sporophyte walls (Figure 4c,d). The LM21 MAb that is specific to mannans lightly labels both generations in electron dense areas near the basal wall layer and in wall ingrowths near the plasmalemma (Figure 4e). No labels were detected for the LM28 MAb.

Of the four AGP-targeting MAbs, only JIM13 and LM6 localized in the placenta of P. patens (Tables 1 and 2). JIM13 epitopes were found along the plasmalemma in wall ingrowths in both generations (Figure 5a,b). Labels for the LM6 MAb targeting AGPs were scattered along electron-lucent regions of wall ingrowths in both generations, with few labels in the basal wall layer (Figure 5c). The JIM8 and LM2 MAbs did not label placental cell walls in P. patens.

Callose, as labeled with the anti-callose MAb, occurred in the sporophyte placental transfer cells in an electron-dense area where the basal wall layer transitioned to wall ingrowths (Figure $5 \mathrm{~d}$; Table 2). Light labeling of anti-callose was seen in clusters throughout the basal wall of gametophyte placental cells (Figure 5e). Extensin, as labeled with the JIM12 MAb, was not detected in P. patens placental cell walls. 


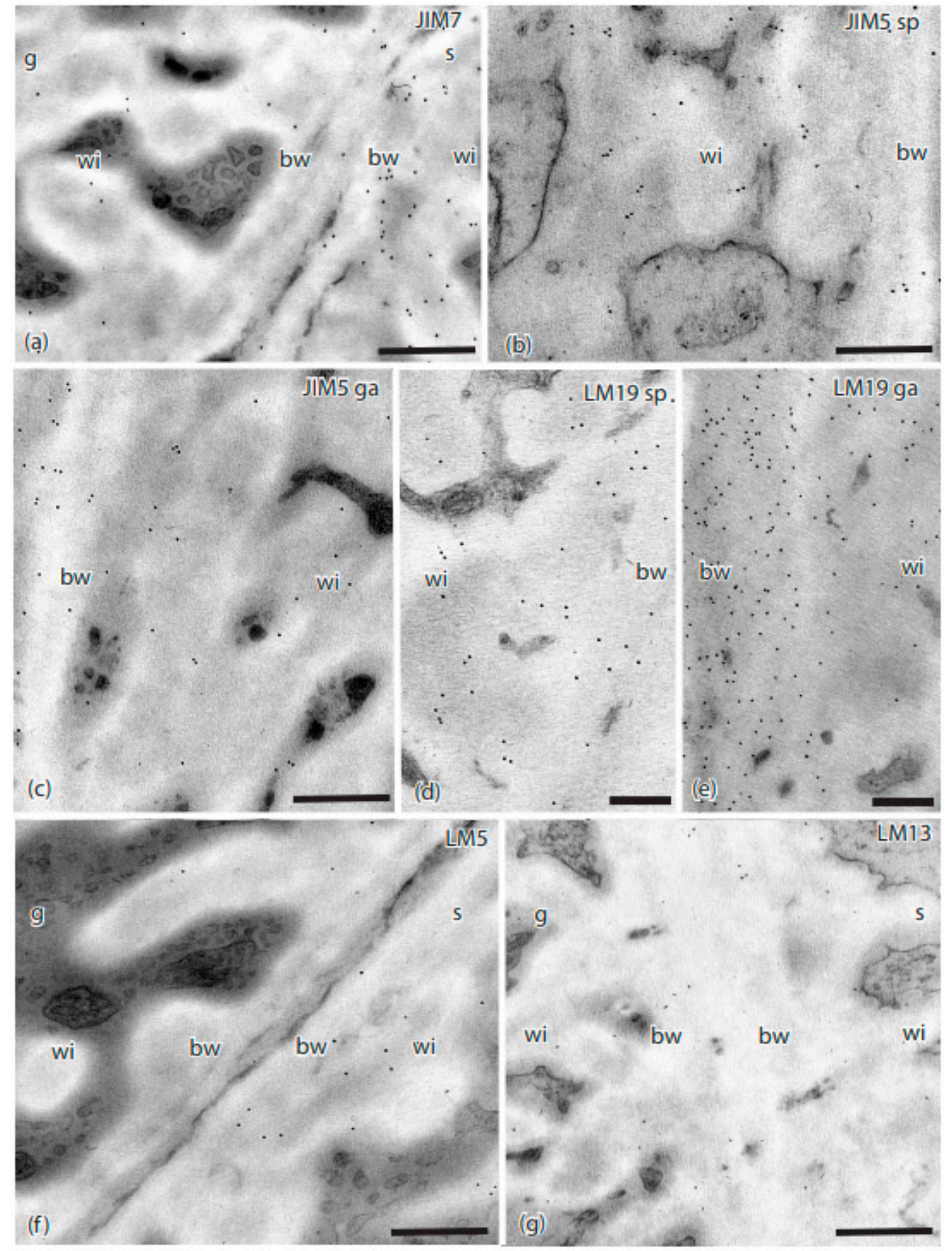

Figure 3. TEMs of Physcomitrium patens placenta showing immunogold labeling with monoclonal antibodies to pectin epitopes. (a) JIM7 labeled sporophyte (s) placental cell walls with more abundance than those in the gametophyte (g). Labeling occurred throughout the basal wall (bw) and the wall ingrowths (wi) on the sporophyte side. (b) JIM5 labeled the basal wall (bw) and wall ingrowths (wi) in sporophyte transfer cells. (c) JIM5 labeled the basal wall (bw) and wall ingrowths (wi) in gametophyte transfer cells. (d) LM19 labels were found in the sporophyte basal wall (bw) and wall ingrowths (wi). (e) LM19 labels on the gametophyte side were more abundant in both basal walls (bw) and wall ingrowths (wi) compared to the sporophyte cell walls. (f) LM5 and (g) LM13 sparsely labeled the basal wall (bw) and wall ingrowths (wi) in both the gametophyte (g) and sporophyte (s) placental cells. Scale bars $=0.5 \mu \mathrm{m}$. 


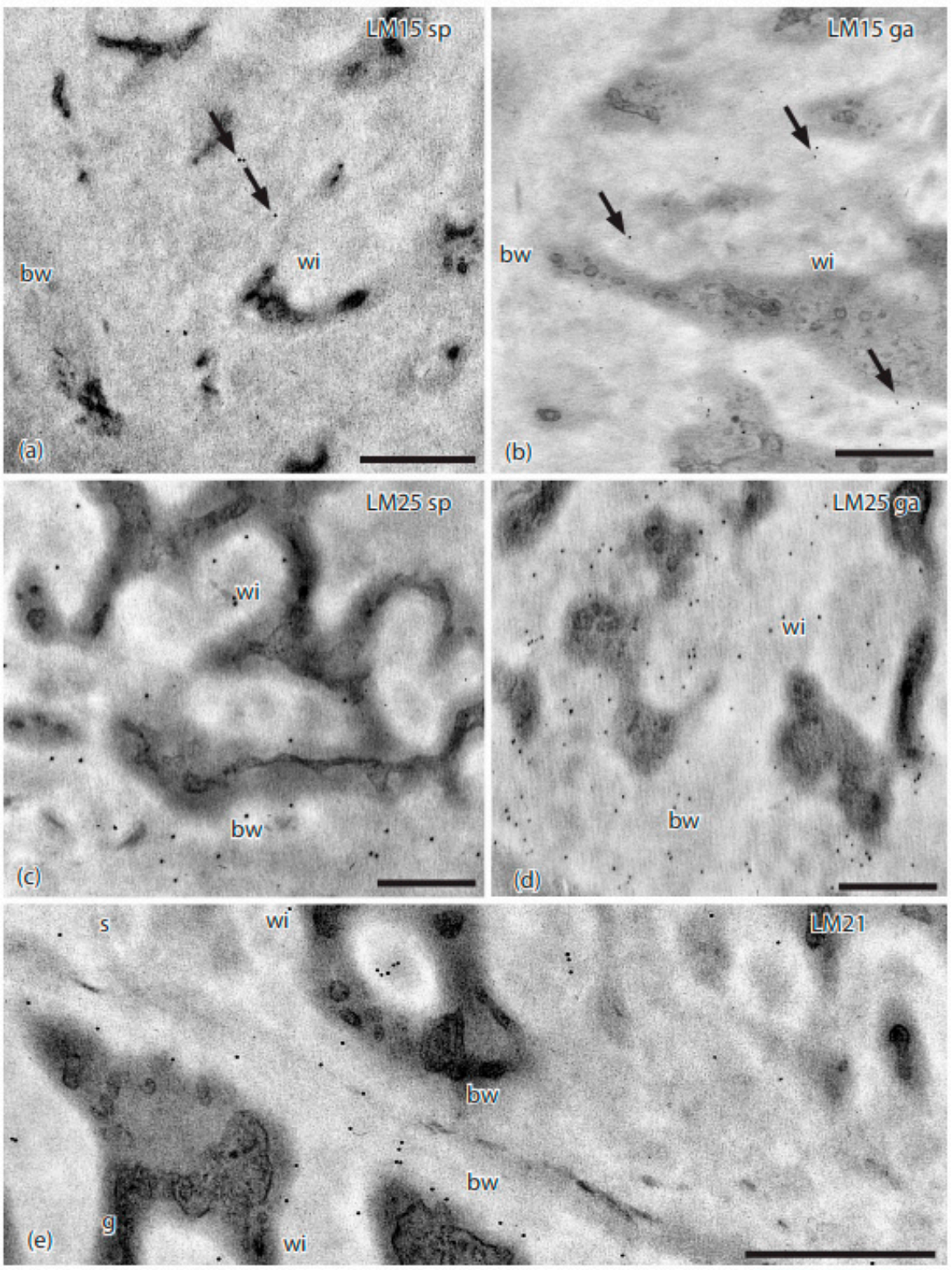

Figure 4. TEMs of Physcomitrium patens placenta showing immunogold labeling with monoclonal antibodies to hemicellulose epitopes. (a) LM15 did not label the basal wall (bw), and sparsely labeled (arrows) the sporophyte cell wall ingrowths (wi). (b) LM15 did not label the basal wall (bw), and sparsely labeled (arrows) the gametophyte cell wall ingrowths (wi). (c) LM25 labeled sporophyte placental cell wall ingrowths (wi) and the basal wall (bw). (d) LM25 labeled gametophyte placental cell wall ingrowths (wi) and the basal wall (bw). (e) LM21 labeled sporophyte (s) and gametophyte (g) transfer cell wall ingrowths (wi) and basal walls (bw). Scale bars $=0.5 \mu \mathrm{m}$. 


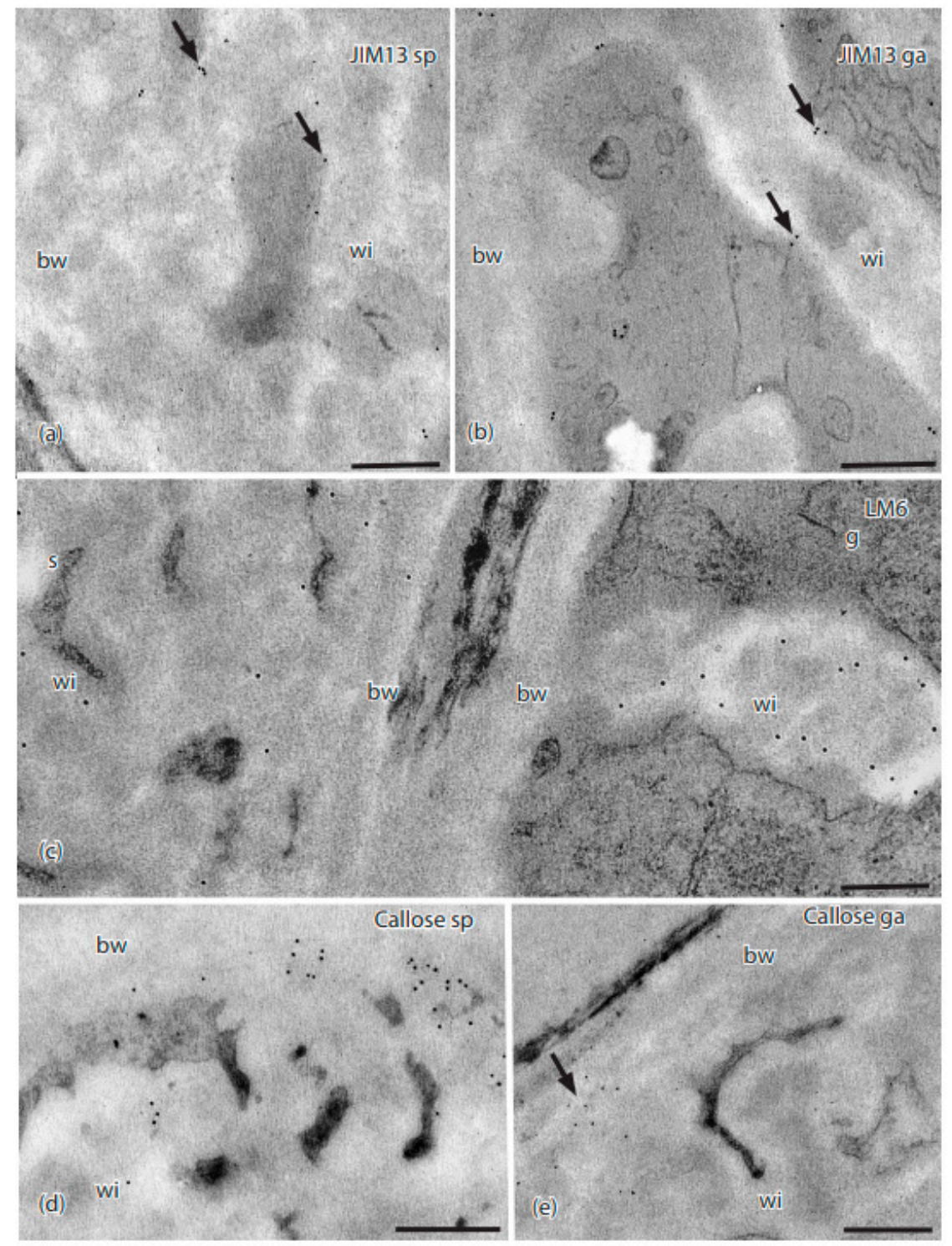

Figure 5. TEMs of Physcomitrium patens placenta showing immunogold labeling with monoclonal antibodies to AGP and callose epitopes. (a) In the sporophyte placental transfer cell, JIM13 labels (arrows) occurred along the plasma membrane and wall ingrowths (wi), but not in the basal wall layer (bw). (b) Labels for JIM13 (arrows) occurred in the gametophyte along the plasma membrane and wall ingrowths (wi), but not in the basal wall (bw). (c) LM6 labels were scattered throughout the wall ingrowths (wi) and basal wall (bw) in the sporophyte (s), and mostly in the electron-lucent area along the edges of the wall ingrowths (wi) in the gametophyte (g) side, with few labels in the basal wall (bw). (d) Sporophyte and (e) gametophyte; labels for anti-callose (arrows) appeared along the outer edge of the basal wall (bw) where it came into contact with the wall ingrowths, with few labels in wall ingrowths (wi). Scale bars $=0.5 \mu \mathrm{m}$.

\section{Discussion}

The cylindrical foot of P. patens extends only slightly into the gametophyte tissue, forming a tapering extension of the short seta. Because the sporophyte takes approximately one month to reach maturation after fertilization, the placenta is short-lived compared to most mosses in which the sporophyte is long-lived, typically one year [36]. Interestingly, the placenta of $M$. polymorpha is similarly short-lived, as the sporophyte also completes development in approximately one month. The placenta of both P. patens and M. polymorpha contains transfer cells with elaborate wall labyrinths on both the sporophyte and gametophyte sides. The massive bulbous foot of Phaeoceros, in turn, persists through the 
growing season, over many months, placing a continuous demand on the gametophyte for nutrient transport across generations. The foot side of the placenta in this hornwort is lined with elongated cells that lack wall ingrowths. During development, these haustorial cells penetrate and interdigitate with gametophytic cells that contain extensive wall ingrowths. These anatomical and developmental differences may account in part for the considerable variability in occurrence, abundance, and types of polymers across the placental cells of these three bryophyte taxa and between the two generations.

As in other bryophytes, cell wall constituents in the P. patens placenta include diverse polymers that include pectins, hemicelluloses, AGPs, and callose (Table 2). In general, placental transfer cell walls of P. patens contain fewer pectins and far fewer AGPs than those of M. polymorpha and Phaeoceros (Figure 6). Transfer cell walls on either side of the placenta of $P$. patens are relatively similar in composition, with slight variation in HG pectins. In the other two bryophytes, cell walls are more variable in abundance and type of polymers across generations, which is especially evident in M. polymorpha (Figure 6).

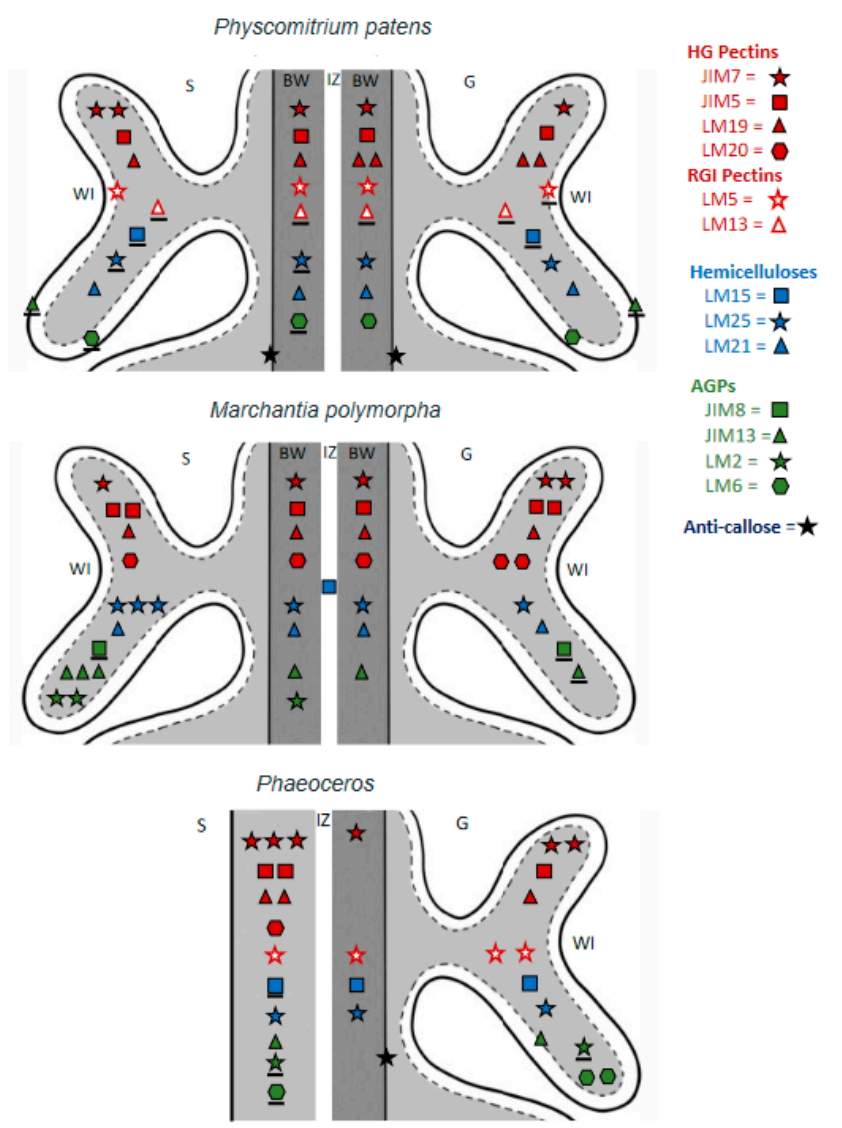

Figure 6. Comparative diagrammatic representation of labeling with 14 MAbs to epitopes of cell wall polymers in three bryophyte placentae: the moss Physcomitrium patens (this study), liverwort Marchantia polymorpha [18], and two species of Phaeoceros [5]. The LM28 and LM12 MAbs yielded no labels in any plant. LM13 labeling in Phaeoceros was inconclusive and omitted. Note: pectins, red; hemicellulose, blue; AGPs, green; callose, black. The number of symbols per MAb corresponds to label intensity as follows: three symbols, very strong; two symbols, strong; one symbol, weak; underlined symbol, present but rare. $S=$ Sporophyte, $\mathrm{G}=$ Gametophyte, $\mathrm{IZ}=$ Intergenerational zone, WI = Wall ingrowth.

Pectins are GalA-containing polysaccharides that often account for a large portion $(\sim 30 \%)$ of the primary cell wall of most angiosperms [37-39]. The pectin composition imparts porosity, permeability, and flexibility to primary walls [40] (Table 3), cell wall properties important to the development and directional transport of placental walls [18]. 
In the placenta of P. patens, pectins are diverse in both generations (Figure 6). Pectins show variable distribution and are particularly abundant on the sporophyte side of the Phaeoceros placenta (Figure 6), which is likely related to the unique intrusive growth of the foot cells and the requirement of haustorial cells to elongate unidirectionally [5].

Table 3. Cell wall polymers, the MAbs that target them, their reported properties, and the supporting references. ${ }^{*} \mathrm{LM} 6$ detects arabinan sidechains in both AGPs and pectin.

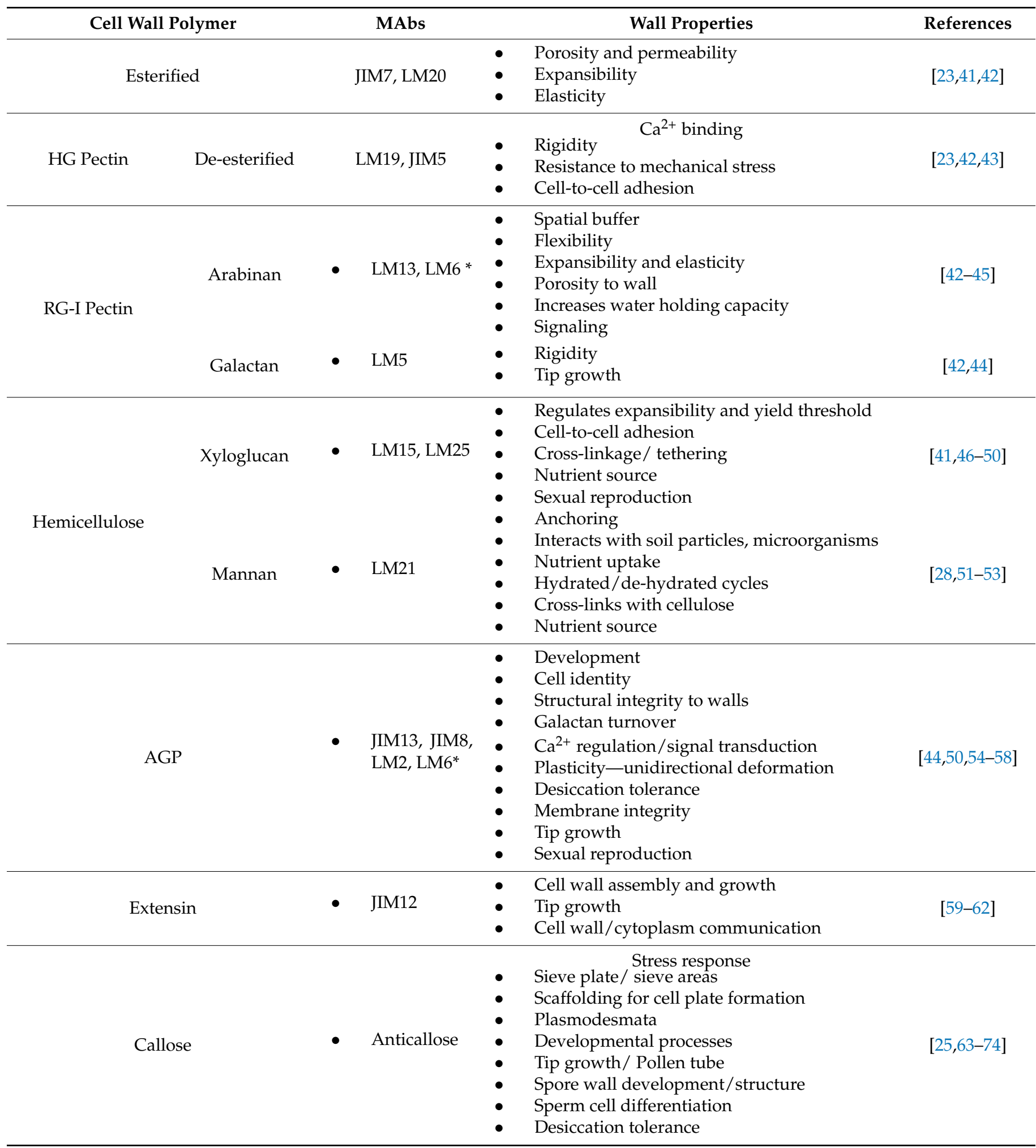


HG pectins play significant roles in cell wall properties and mechanics, and thus affect functions such as apoplastic transport [40] (Table 3). HG is laid down in the methylesterified form, which is stretchable, porous, and has a lower apoplastic $\mathrm{pH}$, which facilitates nutrient uptake by membrane transport proteins [75]. These properties are consistent with the function of transport in placental transfer cell walls, which explains the widespread occurrence of JIM7 epitopes in these bryophytes (Table 3; Figure 6). The LM20 MAb that also recognizes methyl-esterified pectins was not detected in P. patens, but epitopes of this MAb occur in both generations in Marchantia and on the sporophyte side only in Phaeoceros. LM20 epitopes are found in other bryophyte tissues, including the developing gametophore apex and rhizoids of $P$. patens $[70,76]$. The more rigid unesterified HG epitopes (LM19, LM5 MAbs) are common across both generations in the three bryophytes, with higher abundance in the gametophyte than sporophyte cell walls in P. patens, and the reverse in Phaeoceros (Figure 6). Methyl-esterified HGs also occur in the wall ingrowths on both sides of the placenta in Ceratopteris [77], in epidermal transfer cell walls of Vicia [78], and the basal wall layers (but not wall ingrowths) in transfer cells of Elodea [79]. In Elodea, unesterified HG epitopes were not detected in transfer cell wall ingrowths, but do occur in other wall layers [79].

In contrast to HG pectins that are long-chain polymers, RG-I and RG-II have complex side-chain configurations associated with them. The absence of antibodies to RG-II pectins and the low levels of their occurrence in bryophytes (estimated at $1 \%$ of the amount in angiosperm cell walls [80]) has limited our understanding of where they occur in bryophytes. MAbs that detect RG-I pectin, both (1-5)- $\alpha$-L-arabinans (LM13) and (1-4)- $\beta$-Dgalactans (LM5)-containing, showed relatively low levels of labeling in both generations in P. patens. In Phaeoceros, the highest level of labeling of LM5 was present in the gametophyte transfer cell walls, while in P. patens, in the sporophyte transfer cell walls. The placenta of M. polymorpha did not label with MAbs (LM5, LM13) for RGI pectins (Figure 6) [18]. Galactan-rich RG-I is also present in the epidermal transfer cell walls of Vicia, which sparsely contain LM5 epitopes [78]. However, this MAb does not label transfer cell walls in Ceratopteris or Elodea $[77,79]$. The presence of galactan-rich RG-I pectin domains in moss and hornwort placentae is consistent with the hypothesized role of these pectins in directional growth as in root epidermal cells of Arabidopsis seedlings, where they are thought to act as molecular markers for the cell-elongation transition zone [44,81]. Although RG-I pectins are not abundant in the primary cell walls of bryophytes and ferns [25,52], labeling for the LM5 MAb has been observed in the water-conducting cells in some mosses and liverworts [76,82]. These polymers have also been observed in small amounts in P. patens rhizoids [70] and protonemal cells, and in the rhizoids of Ceratopteris [83].

Xyloglucans (LM15), galactoxyloglucan (LM25), and mannans (LM21) were hemicellulose constituents of the placental cell wall in P. patens (Table 2). As in Marchantia and Phaeoceros, there was no labeling for glucoronoxylans (LM28) in either generation. Galactoxyloglucan was more abundant than xyloglucans in the P. patens placenta, especially on the gametophyte side. In Phaeoceros, light labeling for galactoxyloglucan occurred in both generations, and in Marchantia, these epitopes were more abundant in the sporophyte generation. Using a polyclonal antibody for xyloglucan, Vaughn et al. [78] observed an abundance of this polymer in Vicia transfer cell walls. Xyloglucans are common cell wall polymers known to associate with both cellulose networks and acidic pectins across land plants [81,84]. A possible function in transfer cell walls is as a regulator of cell wall extensibility by weakening the cellulose network to allow slippage during cell growth $[41,42]$.

The transfer cell walls of both generations in P. patens had low levels of mannancontaining hemicellulose, which was similar to the placenta of Marchantia, but differed from that of Phaeoceros, which lacks mannans. Because mannans also occur in protonemata and rhizoids in P. patens, these polymers have been speculated to facilitate nutrient uptake, water sensing, and cell wall reinforcement, all of which would be important and useful properties for transfer cell walls (Table 3) [52,53,85]. The combination of mannans and small amounts of arabinan-containing RG-I pectin in P. patens may enhance water and 
nutrient movement, while the small amounts of galactan-containing RG-I may increase rigidity of these walls $[52,53,85]$.

AGPs are proteoglycans made of a protein backbone that is heavily O-glycosylated (90\% of the overall mass). As seen in Figure 6, arabinogalactan proteins (AGPs) were the most variable cell wall polymers present in bryophyte placental cell walls. Transfer cell walls in the $P$. patens placenta had lower diversity and amounts of AGPs than in Marchantia and Phaeoceros. Gametophyte cell walls in the placenta were only slightly richer in AGPs than those of the sporophyte in P. patens. In Marchantia, sporophyte cell wall ingrowths showed an abundance of AGPs compared with gametophyte wall ingrowths. In gametophyte transfer cells, AGP labeling was light in Phaeoceros and even less abundant in Marchantia. AGPs were abundant in placental transfer cell walls of the Ceratopteris gametophyte, with less labeling observed in sporophyte cells [77]. Vaughn et al. (2006) found AGP epitopes in Vicia wall ingrowths along the plasmalemma around the outer edges of cell wall ingrowths adjacent to an electron-lucent layer that contained callose. AGP epitopes were not detected in Eldoea leaf transfer cells [79].

The varied and important roles of AGPs in plant biological processes are increasingly becoming clear [86]. These proteoglycans are speculated to be involved in differentiation, cell-to-cell recognition, embryogenesis, programmed cell death, tip growth, pectin plasticization, and $\mathrm{pH}$-dependent signaling by releasing $\mathrm{Ca}^{2+}$ as a secondary messenger that regulates development [53,55,87-90] (Table 3). The contribution of AGPs to placental development and functions is likely varied. Regulated signaling by AGPs would facilitate the interaction between generations, and the systematic directional transport of nutrients. In angiosperms, cytosolic $\mathrm{Ca}^{2+}$ accumulation is important in the development of reticulate cell wall ingrowths that are similar to those in bryophytes [91]. AGPs are also hypothesized to act as markers that aid in directing the polarized growth of wall ingrowths [92]. AGPs may act as pectin plasticizers by preventing HG domain crosslinking [93].

Across bryophytes, AGPs have been observed in the walls of water-conducting cells in both mosses and liverworts [82], in apical cell extensions of protonemata and water balance in P. patens [57,94], and in hyaline cell walls in Sphagnum [95]. AGP have been implicated in protonemata differentiation [96], cell wall regeneration of the cultured protoplasts [97], and cell plate formation in M. polymorpha [98]. Their significance in sexual reproduction has been observed in the process of spermatogenesis in Ceratopteris [50] and the moss Aulacomnium palsutre [99]. The female gametes of Ceratopteris also express AGPs during development [58].

Callose occurs in both generations of P. patens along the electron-dense base of wall ingrowths. Callose labeling does not occur in the Marchantia placenta, and in Phaeoceros it is restricted to the gametophyte generation around plasmodesmata. In contrast, callose is more prominent in Vicia and P. sativum cell wall callose, where it is localized in the electron-dense areas of wall ingrowths and the basal wall $[79,100]$.

As has been observed in tracheophytes, unique cell wall compositions characterize transfer cells across taxa, and the variability in the placentae of the three bryophytes may be explained in part by differences in the developmental and physiological interactions between the generations, and the longevity of the sporophyte and associated protective structures. It is logical to link the differential polymer composition in the placenta of Phaeoceros to differences in development and function between gametophyte transfer cells and sporophyte haustorial cells [5]. The placenta of hornworts is long-lived and nutrient demands from the growing sporophyte are high, so differential cell wall composition would make sense for efficient unidirectional transport [5]. Generational differences in cell wall polymers are also evident in Marchantia, and these also likely reflect directional movement [18]. In this liverwort, the foot is small and anchor-shaped and the sporophyte is surrounded by three protective structures (calyptra, pseudoperianth, and involucre) throughout development $[18,101]$. A constant nutrient transport via the gametophyte would be critical for sporophyte development, as photosynthetic activity of this generation is limited. Compared to most moss sporophytes that persist for approximately one year, 
the longevity of the P. patens sporophyte is highly abbreviated. The sporophyte is green throughout development with significant autonomy. This may explain the lack of generational variability in placental transfer cell walls in this moss. Although placental cell walls in P. patens are less pectin- and AGP-rich than those of M. polymorpha and Phaeoceros, the ratios of carbohydrates in these transfer cell walls are similar to those described in moss primary cell walls $[76,84,102]$. Compositional similarities between wall ingrowths and primary cell walls suggest that wall ingrowths may simply be extensions of the primary cell wall in P. patens, as hypothesized in Vicia by Vaughn et al. [78]. Whether this hypothesis is valid, or $P$. patens placental cell walls simply represent an evolutionary reduction in complexity awaits further testing with immunolabelling on placentae of mosses with more extended life cycles.

Transfer cells have evolved multiple times and are important in directional transport and tissue function across algae, fungi and plants [15,103-105]. It is therefore surprising that transfer cell wall composition is poorly characterized and known only from Elodea, Vicia, Pisum, and the placenta of three bryophytes. The occurrence, abundance, and types of polymers is considerably different among these taxa and between the two generations, suggesting that similarity in function and morphology of cell walls does not require a common cell wall composition. We propose that the specific developmental and life history traits of plants may provide even more important clues in understanding the basis for these differences. Understanding which polymers are present, their abundance, and their associations with each other is foundational to further work on plant cell walls. Additional studies of cell wall polymers on a broad spectrum of tissue types across bryophyte diversity are necessary to assess the variability in cell wall composition and its impact on the function and evolution of cell walls across plants.

Author Contributions: J.S.H. contributed to the conceptualization of this work. J.S.H. performed the immunogold labeling, curation of data, and analyzed the data. As well as contributing to the writing of the manuscript and developing the figures. K.S.R. contributed to the conceptualization of this work. She both analyzed and synthesized the data. As well as contributing to the writing of the manuscript, developing the figures, and securing funding. All authors have read and agreed to the published version of the manuscript.

Funding: This work was supported by grants from the National Science Foundation (NSF 1758497) and the National Institutes of Health (NIH 5R25GM107760-07).

Acknowledgments: We thank Laxmi Sagwan-Barkdoll and Renee Lopez-Swalls for their assistance with this research. Jeffrey Duckett, Dae-Yeon Suh, Neil Ashton and Masaki Shimamura provided valuable insight on the life histories of Physcomitrium and Marchantia. This work was supported by grants from the National Science Foundation (NSF 1758497) and the National Institutes of Health (NIH 5R25GM107760-07).

Conflicts of Interest: The authors declare no conflict of interest.

\section{References}

1. Ligrone, R.; Duckett, J.G.; Renzaglia, K.S. The Gametophyte-Sporophyte Junction in Land Plants. Adv. Bot. Res. 1993, 19, 231-318. [CrossRef]

2. Ligrone, R.; Duckett, J.G.; Renzaglia, K.S. The origin of the sporophyte shoot in land plants: A bryological perspective. Ann. Bot. 2012, 110, 935-941. [CrossRef]

3. Gunning, B.E.; Pate, J.S. “Transfer cells" plant cells with wall ingrowths, specialized in relation to short distance transport of solutes-Their occurrence, structure, and development. Protoplasma 1969, 68, 107-133. [CrossRef]

4. Thompson, R.D.; Hueros, G.; Becker, H.-A.; Maitz, M. Development and functions of seed transfer cells. Plant Sci. 2001, 160, 775-783. [CrossRef]

5. Henry, J.S.; Ligrone, R.; Vaughn, K.C.; Lopez, R.A.; Renzaglia, K.S. Cell wall polymers in the Phaeoceros placenta reflect devel-opmental and functional differences across generations. Bryophyt. Divers. Evol. 2021, 43, 265-283.

6. McCurdy, D.W.; Patrick, J.W.; Offler, C.E. Wall ingrowth formation in transfer cells: Novel examples of localized wall deposition in plant cells. Curr. Opin. Plant Biol. 2008, 11, 653-661. [CrossRef] [PubMed]

7. Talbot, M.J.; Franceschi, V.R.; McCurdy, D.W.; Offler, C.E. Wall ingrowth architecture in epidermal transfer cells of Vicia faba cotyledons. Protoplasma 2001, 215, 191-203. [CrossRef] 
8. Pate, J.S.; Gunning, B.E.S.; Milliken, F.F. Function of transfer cells in the nodal regions of stems, particularly in relation to the nutrition of young seedlings. Protoplasma 1970, 71, 313-334. [CrossRef]

9. Cochrane, M.P.; Duffus, C.M. The nucellar projection and modified aleurone in the crease region of developing caryopses of barley (Hordeum vulgare L. var. distichum). Protoplasma 1980, 103, 361-375. [CrossRef]

10. Zee, S.-Y.; O'Brien, T.P. Aleurone Transfer Cells and other Structural Features of the Spikelet of Millet. Aust. J. Biol. Sci. 1971, 24, 391-395. [CrossRef]

11. Patrick, J.W.; Offler, C.E. Compartmentation of transport and transfer events in developing seeds. J. Exp. Bot. 2001, 52, 551-564. [CrossRef] [PubMed]

12. Tegeder, M.; Wang, X.-D.; Frommer, W.; Offler, C.E.; Patrick, J.W.B. Sucrose transport into developing seeds of Pisum sativum L. Plant J. 1999, 18, 151-161. [CrossRef] [PubMed]

13. Faraday, C.D.; Thompson, W.W. Structural aspects of the salt glands of the Plumbaginaceae. J. Exp. Bot. 1986, 37, 461-470. [CrossRef]

14. Berry, A.M.; McIntyre, L.; McCully, M.E. Fine structure of root hair infection leading to nodulation in the Frankia-Alnus sym-biosis. Can. J. Bot. 1986, 64, 292-305. [CrossRef]

15. Gunning, B.E.S.; Pate, J.S.; Minchin, F.R.; Marks, I. Quantitative aspects of transfer cell structure in relation to vein loading in leaves and solute transport in legume nodules. Symp. Soc. Exp. Biol. 1974, 28, 87-126.

16. Regmi, K.C.; Li, L.; Gaxiola, R.A. Alternate Modes of Photosynthate Transport in the Alternating Generations of Physcomitrella patens. Front. Plant Sci. 2017, 8, 1956. [CrossRef] [PubMed]

17. Courtice, G.R.M.; Ashton, N.W.; Cove, D.J. Evidence for the restricted passage of metabolites into the sporophyte of the moss Physcomitrella patens (Hedw.) Br. Eur. J. Bryol. 1978, 10, 191-198. [CrossRef]

18. Henry, J.S.; Lopez, R.A.; Renzaglia, K.S. Differential localization of cell wall polymers across generations in the placenta of Marchantia polymorpha. J. Plant Res. 2020, 133, 911-924. [CrossRef]

19. Renzaglia, K.S.; Lopez, R.A.; Henry, J.S.; Flowers, N.D.; Vaughn, K.C. Transmission Electron Microscopy of Centrioles, Basal Bodies and Flagella in Motile Male Gametes of Land Plants. Bio-Protocol 2017, 7. [CrossRef]

20. Lopez, R.A.; Mansouri, K.; Henry, J.S.; Flowers, N.D.; Vaughn, K.C.; Renzaglia, K.S. Immunogold localization of molecular constituents associated with basal bodies, flagella, and extracellular matrices in male gametes of land plants. Bio-Protocol 2017, 7, e2599. [CrossRef]

21. Willats, W.G.; Limberg, G.; Buchholt, H.C.; van Alebeek, G.-J.; Benen, J.; Christensen, T.M.; Visser, J.; Voragen, A.; Mikkelsen, J.D.; Knox, P. Analysis of pectic epitopes recognised by hybridoma and phage display monoclonal antibodies using defined oligosaccharides, polysaccharides, and enzymatic degradation. Carbohydr. Res. 2000, 327, 309-320. [CrossRef]

22. Knox, P.; Linstead, P.J.; King, J.; Cooper, C.; Roberts, K. Pectin esterification is spatially regulated both within cell walls and between developing tissues of root apices. Planta 1990, 181, 512-521. [CrossRef] [PubMed]

23. Verhertbruggen, Y.; Marcus, S.E.; Haeger, A.; Ordaz-Ortiz, J.J.; Knox, P. An extended set of monoclonal antibodies to pectic homogalacturonan. Carbohydr. Res. 2009, 344, 1858-1862. [CrossRef] [PubMed]

24. Jones, L.; Seymour, G.; Knox, J.P. Localization of Pectic Galactan in Tomato Cell Walls Using a Monoclonal Antibody Specific to (1[-> 4)- $\beta$-D-Galactan. Plant Physiol. 1997, 113, 1405-1412. [CrossRef] [PubMed]

25. Moller, I.; Sørensen, I.; Bernal, A.; Blaukopf, C.; Lee, K.; Øbro, J.; Pettolino, F.; Roberts, A.; Mikkelsen, J.D.; Knox, P.; et al. High-throughput mapping of cell-wall polymers within and between plants using novel microarrays. Plant J. 2007, 50, 1118-1128. [CrossRef]

26. Marcus, S.E.; Verhertbruggen, Y.; Hervé, C.; Ordaz-Ortiz, J.J.; Farkas, V.; Pedersen, H.L.; Willats, W.G.T.; Knox, J.P. Pectic homogalacturonan masks abundant sets of xyloglucan epitopes in plant cell walls. BMC Plant Biol. 2008, 8, 60. [CrossRef]

27. Pedersen, H.L.; Fangel, J.U.; McCleary, B.; Ruzanski, C.; Rydahl, M.G.; Ralet, M.-C.; Farkas, V.; von Schantz, L.; Marcus, S.E.; Andersen, M.C.; et al. Versatile High Resolution Oligosaccharide Microarrays for Plant Glycobiology and Cell Wall Research. J. Biol. Chem. 2012, 287, 39429-39438. [CrossRef]

28. Marcus, S.E.; Blake, A.W.; Benians, T.A.S.; Lee, K.J.D.; Poyser, C.; Donaldson, L.; Leroux, O.; Rogowski, A.; Petersen, H.L.; Boraston, A.; et al. Restricted access of proteins to mannan polysaccharides in intact plant cell walls. Plant J. 2010, 64, 191-203. [CrossRef]

29. Cornuault, V.; Buffetto, F.; Rydahl, M.; Marcus, S.E.; Torode, T.; Xue, J.; Crépeau, M.-J.; Faria-Blanc, N.; Willats, W.G.T.; Du Pree, P.; et al. Monoclonal antibodies indicate low-abundance links between heteroxylan and other glycans of plant cell walls. Planta 2015, 242, 1321-1334. [CrossRef]

30. Yates, E.A.; Valdor, J.-F.; Haslam, S.M.; Morris, H.R.; Dell, A.; Mackie, W.; Knox, P. Characterization of carbohydrate structural features recognized by anti-arabinogalactan-protein monoclonal antibodies. Glycobiology 1996, 6, 131-139. [CrossRef]

31. Willats, W.; Marcus, S.E.; Knox, P. Generation of a monoclonal antibody specific to $(1 \rightarrow 5)-\alpha$-l-arabinan. Carbohydr. Res. 1998, 308 , 149-152. [CrossRef]

32. Pennell, R.I.; Janniche, L.; Kjellbom, P.; Scofield, G.N.; Peart, J.M.; Roberts, K. Developmental Regulation of a Plasma Membrane Arabinogalactan Protein Epitope in Oilseed Rape Flowers. Plant Cell 1991, 3, 1317-1326. [CrossRef] [PubMed]

33. Smallwood, M.; Yates, E.A.; Willats, W.G.; Martin, H.; Knox, P. Immunochemical comparison of membrane-associated and secreted arabinogalactan-proteins in rice and carrot. Planta 1996, 198, 452-459. [CrossRef] 
34. Meikle, P.; Bonig, I.; Hoogenraad, N.J.; Clarke, A.E.; Stone, B.A. The location of $(1 \rightarrow 3)-\beta$-glucans in the walls of pollen tubes of Nicotiana alata using a $(1 \rightarrow 3)-\beta$-glucan-specific monoclonal antibody. Planta 1991, 185, 1-8. [CrossRef] [PubMed]

35. Smallwood, M.; Beven, A.; Donovan, N.; Neill, S.J.; Peart, J.; Roberts, K.; Knox, P. Localization of cell wall proteins in relation to the developmental anatomy of the carrot root apex. Plant J. 1994, 5, 237-246. [CrossRef]

36. Schmid, R.; Crum, H. Structural Diversity of Bryophytes; University of Michigan Herbarium: Ann Arbor, MI, USA, $2001 ;$ p. 379.

37. Ridley, B.L.; O'Neill, M.A.; Mohnen, D. Pectins: Structure, biosynthesis, and oligogalacturonide-related signaling. Phytochemistry 2001, 57, 929-967. [CrossRef]

38. O'Neill, M.A.; York, W.S.; Roberts, J.A.; Evan, D.; McManus, M.T.; Rose, J.K.C. The Composition and Structure of Plant Primary Cell Walls. Ann. Plant Rev. Online 2018, 1-54. [CrossRef]

39. Carpita, N.C. Structure and biogenesis of the cell walls of grasses. Annu. Rev. Plant Biol. 1996, 47, 445-476. [CrossRef]

40. Caffall, K.H.; Mohnen, D. The structure, function, and biosynthesis of plant cell wall pectic polysaccharides. Carbohydr. Res. 2009, 344, 1879-1900. [CrossRef] [PubMed]

41. Braybrook, S.A.; Jönsson, H. Shifting foundations: The mechanical cell wall and development. Curr. Opin. Plant Biol. 2016, 29, 115-120. [CrossRef] [PubMed]

42. Cornuault, V.; Buffetto, F.; Marcus, S.E.; Crépeau, M.J.; Guillon, F.; Ralet, M.C.; Knox, P. LM6-M: A high avidity rat monoclonal antibody to pectic $\alpha-1,5-\mathrm{L}-$ arabinan. Bio Rxiv Plant Bio. 2017. [CrossRef]

43. Verhertbruggen, Y.; Marcus, S.E.; Chen, J.; Knox, J.P. Cell Wall Pectic Arabinans Influence the Mechanical Properties of Arabidopsis thaliana Inflorescence Stems and Their Response to Mechanical Stress. Plant Cell Physiol. 2013, 54, 1278-1288. [CrossRef] [PubMed]

44. McCartney, L.; Steele-King, C.G.; Jordan, E.; Knox, J.P. Cell wall pectic $(1 \rightarrow 4)$ - $\beta$-d-galactan marks the acceleration of cell elongation in theArabidopsisseedling root meristem. Plant J. 2003, 33, 447-454. [CrossRef] [PubMed]

45. Jones, L.; Milne, J.L.; Ashford, D.; McQueen-Mason, S.J. Cell wall arabinan is essential for guard cell function. Proc. Natl. Acad. Sci. USA 2003, 100, 11783-11788. [CrossRef] [PubMed]

46. Whitney, S.E.C.; Wilson, E.; Webster, J.; Bacic, A.; Reid, J.S.G.; Gidley, M.J. Effects of structural variation in xyloglucan polymers on interactions with bacterial cellulose. Am. J. Bot. 2006, 93, 1402-1414. [CrossRef]

47. Chanliaud, E.; Burrows, K.M.; Jeronimidis, G.; Gidley, M.J. Mechanical properties of primary plant cell wall analogues. Planta 2002, 215, 989-996. [CrossRef]

48. Ordaz-Ortiz, J.J.; Marcus, S.E.; Knox, J.P. Cell Wall Microstructure Analysis Implicates Hemicellulose Polysaccharides in Cell Adhesion in Tomato Fruit Pericarp Parenchyma. Mol. Plant 2009, 2, 910-921. [CrossRef]

49. Bunterngsook, B.; Eurwilaichitr, L.; Thamchaipenet, A.; Champreda, V. Binding characteristics and synergistic effects of bacterial expansins on cellulosic and hemicellulosic substrates. Bioresour. Technol. 2015, 176, 129-135. [CrossRef]

50. Lopez, R.A.; Renzaglia, K.S. Multiflagellated sperm cells of Ceratopteris richardii are bathed in arabinogalactan proteins throughout development. Am. J. Bot. 2014, 101, 2052-2061. [CrossRef]

51. Scheller, H.V.; Ulvskov, P. Hemicelluloses. Annu. Rev. Plant Biol. 2010, 61, 263-289. [CrossRef]

52. Dehors, J.; Mareck, A.; Kiefer-Meyer, M.-C.; Menu-Bouaouiche, L.; Lehner, A.; Mollet, J.-C. Evolution of Cell Wall Polymers in Tip-Growing Land Plant Gametophytes: Composition, Distribution, Functional Aspects and Their Remodeling. Front. Plant Sci. 2019, 10, 441. [CrossRef]

53. Plancot, B.; Gügi, B.; Mollet, J.-C.; Loutelier-Bourhis, C.; Govind, S.R.; Lerouge, P.; Follet-Gueye, M.-L.; Vicré, M.; Alfonso, C.; Nguema-Ona, E.; et al. Desiccation tolerance in plants: Structural characterization of the cell wall hemicellulosic polysaccharides in three Selaginella species. Carbohydr. Polym. 2018, 208, 180-190. [CrossRef] [PubMed]

54. Torode, T.A.; O’Neill, R.; Marcus, S.E.; Cornuault, V.; Pose-Albacete, S.; Lauder, R.P.; Kracun, S.K.; Rydahl, M.G.; Andersen, M.C.F.; Willats, W.G.T.; et al. Branched Pectic Galactan in Phloem-Sieve-Element Cell Walls: Implications for Cell Mechanics. Plant Physiol. 2017, 176, 1547-1558. [CrossRef]

55. Lamport, D.T.A.; Varnai, P.; Seal, C. Back to the future with the AGP-Ca2+ flux capacitor. Ann. Bot. 2014, 114, 1069-1085. [CrossRef]

56. Lamport, D.T.A.; Tan, L.; Held, M.A.; Kieliszewski, M.J. Pollen tube growth and guidance: Occam's razor sharpened on a molecular arabinogalactan glycoprotein Rosetta Stone. New Phytol. 2018, 217, 491-500. [CrossRef]

57. Lee, K.J.; Sakata, Y.; Mau, S.-L.; Pettolino, F.; Bacic, A.; Quatrano, R.S.; Knight, C.D.; Knox, J.P. Arabinogalactan Proteins Are Required for Apical Cell Extension in the Moss Physcomitrella patens. Plant Cell 2005, 17, 3051-3065. [CrossRef]

58. Lopez, R.A.; Renzaglia, K.S. Arabinogalactan proteins and arabinan pectins abound in the specialized matrices surrounding female gametes of the fern Ceratopteris richardii. Planta 2016, 243, 947-957. [CrossRef] [PubMed]

59. Diet, A.; Link, B.; Seifert, G.J.; Schellenberg, B.; Wagner, U.; Pauly, M.; Reiter, W.-D.; Ringli, C.; Saint-Jore-Dupas, C.; Nebenführ, A.; et al. The Arabidopsis Root Hair Cell Wall Formation Mutantlrx1Is Suppressed by Mutations in theRHM1Gene Encoding a UDP-L-Rhamnose Synthase. Plant Cell 2006, 18, 1630-1641. [CrossRef] [PubMed]

60. Ringli, C. Monitoring the Outside: Cell Wall-Sensing Mechanisms. Plant Physiol. 2010, 153, 1445-1452. [CrossRef]

61. Velasquez, S.M.; Salter, J.S.; Dorosz, J.G.; Petersen, B.L.; Estevez, J.M. Recent Advances on the Posttranslational Modifications of EXTs and Their Roles in Plant Cell Walls. Front. Plant Sci. 2012, 3, 93-99. [CrossRef]

62. Bascom, C.S.; Winship, L.J.; Bezanilla, M. Simultaneous imaging and functional studies reveal a tight correlation between calcium and actin networks. Proc. Natl. Acad. Sci. USA 2018, 115, E2869-E2878. [CrossRef] 
63. Samuels, A.L.; Giddings, T.H.; Staehelin, L.A. Cytokinesis in tobacco BY-2 and root tip cells: A new model of cell plate formation in higher plants. J. Cell Biol. 1995, 130, 1345-1357. [CrossRef]

64. Vaughn, K.C.; Hoffman, J.C.; Hahn, M.G.; Staehelin, L.A. The herbicide dichlobenil disrupts cell plate formation: Immunogold characterization. Protoplasma 1996, 194, 117-132. [CrossRef]

65. Renzaglia, K.S.; Garbary, D.J. Motile Gametes of Land Plants: Diversity, Development, and Evolution. Crit. Rev. Plant Sci. 2001, 20, 107-213. [CrossRef]

66. Lopez, R.A.; Renzaglia, K.S. The Ceratopteris (fern) developing motile gamete walls contain diverse polysaccharides, but not pectin. Planta 2018, 247, 393-404. [CrossRef] [PubMed]

67. Schuette, S.; Wood, A.J.; Geisler, M.; Geisler-Lee, J.; Ligrone, R.; Renzaglia, K.S. Novel localization of callose in the spores of Physcomitrella patens and phylogenomics of the callose synthase gene family. Ann. Bot. 2009, 103, 749-756. [CrossRef] [PubMed]

68. Cao, J.-G.; Dai, X.-L.; Zou, H.-M.; Wang, Q.-X. Formation and development of rhizoids of the liverwort Marchantia polymorpha ${ }^{1}$. J. Torrey Bot. Soc. 2014, 141, 126-134. [CrossRef]

69. Tang, C.T.C. The Wound Response in Arabidopsis thaliana and Physcomitrella patens. Ph.D. Thesis, Rutgers University-Graduate School-New Brunswick, New Brunswick, NJ, USA, 2007.

70. Berry, E.A.; Tran, M.L.; Dimos, C.S.; Budziszek, M.J.; Scavuzzo-Duggan, T.; Roberts, A.W. Immuno and Affinity Cytochemical Analysis of Cell Wall Composition in the Moss Physcomitrella patens. Front. Plant Sci. 2016, 7, 248. [CrossRef]

71. Bopp, M.; Quader, H.; Thoni, C.; Sawidis, T.; Schnepf, E. Filament Disruption in Funaria Protonemata: Formation and Disintegration of Tmema Cells. J. Plant Physiol. 1991, 137, 273-284. [CrossRef]

72. Renzaglia, K.S.; Lopez, R.A.; Johnson, E.E. Callose is integral to the development of permanent tetrads in the liverwort Sphaerocarpos. Planta 2014, 241, 615-627. [CrossRef] [PubMed]

73. Renzaglia, K.S.; Lopez, R.A.; Welsh, R.D.; Owen, H.A.; Merced, A. Callose in sporogenesis: Novel composition of the inner spore wall in hornworts. Plant Syst. Evol. 2020, 306, 1-9. [CrossRef]

74. Radford, J.E.; Vesk, M.; Overall, R.L. Callose deposition at plasmodesmata. Protoplasma 1998, 201, 30-37. [CrossRef]

75. Clausen, M.H.; Willats, W.G.; Knox, J.P. Synthetic methyl hexagalacturonate hapten inhibitors of anti-homogalacturonan monoclonal antibodies LM7, JIM5 and JIM7. Carbohydr. Res. 2003, 338, 1797-1800. [CrossRef]

76. Mansouri, K. Comparative Ultrastructure of Apical Cells and Derivatives in Bryophytes, with Special Reference to Plasmodesmata. Ph.D. Thesis, Southern Illinois University at Carbondale, Carbondale, IL, USA, 2012.

77. Johnson, G.P. Early Embryology of Ceratopteris Richardii and Immunocytochemestry of Placental Transfer Cell Wall Ingrowths. Master's Thesis, Southern Illinois University, Carbondale, IL, USA, 2008.

78. Vaughn, K.C.; Talbot, M.J.; Offler, C.E.; McCurdy, D.W. Wall Ingrowths in Epidermal Transfer Cells of Vicia faba Cotyledons are Modified Primary Walls Marked by Localized Accumulations of Arabinogalactan Proteins. Plant Cell Physiol. 2006, 48, 159-168. [CrossRef] [PubMed]

79. Ligrone, R.; Vaughn, K.C.; Rascio, N. A cytochemical and immunocytochemical analysis of the wall labyrinth apparatus in leaf transfer cells in Elodea canadensis. Ann. Bot. 2011, 107, 717-722. [CrossRef]

80. Matsunaga, T.; Ishii, T.; Matsumoto, S.; Higuchi, M.; Darvill, A.; Albersheim, P.; O'Neill, M.A. Occurrence of the Primary Cell Wall Polysaccharide Rhamnogalacturonan II in Pteridophytes, Lycophytes, and Bryophytes. Implications for the Evolution of Vascular Plants. Plant Physiol. 2004, 134, 339-351. [CrossRef]

81. Cornuault, V.; Pose, S.; Knox, J.P. Extraction, texture analysis and polysaccharide epitope mapping data of sequential extracts of strawberry, apple, tomato and aubergine fruit parenchyma. Data Brief 2018, 17, 314-320. [CrossRef]

82. Lee, K.J.; Sakata, Y.; Mau, S.-L.; Pettolino, F.; Bacic, A.; Quatrano, R.S.; Knight, C.D.; Knox, J.P. Diversity in the distribution of polysaccharide and glyco-protein epitopes in the cell walls of bryophytes: New evidence for multiple evolution of waterconducting cells. New Phytol. 2002, 156, 491-508.

83. Eeckhout, S.; Leroux, O.; Willats, W.G.T.; Popper, Z.; Viane, R.L.L. Comparative glycan profiling of Ceratopteris richardii 'C-Fern' gametophytes and sporophytes links cell-wall composition to functional specialization. Ann. Bot. 2014, 114, 1295-1307. [CrossRef]

84. Popper, Z. Primary Cell Wall Composition of Bryophytes and Charophytes. Ann. Bot. 2003, 91, 1-12. [CrossRef]

85. Moore, J.P. Understanding drought (and desiccation) tolerance in woody perennials: Lessons from a resurrection plant. S. Afr. J. Bot. 2009, 75, 412-413. [CrossRef]

86. Happ, K.; Classen, B. Happ Arabinogalactan-Proteins from the Liverwort Marchantia polymorpha L., a Member of a Basal Land Plant Lineage, Are Structurally Different to Those of Angiosperms. Plants 2019, 8, 460. [CrossRef]

87. Nguema-Ona, E.; Moore, J.; Fagerström, A.; Fangel, J.U.; Willats, W.; Hugo, A.; Vivier, M.A. Profiling the main cell wall polysaccharides of tobacco leaves using high-throughput and fractionation techniques. Carbohydr. Polym. 2012, 88, 939-949. [CrossRef]

88. Gaspar, Y.; Johnson, K.L.; McKenna, J.A.; Bacic, A.; Schultz, C.J. The complex structures of arabinogalactan-proteins and the journey towards understanding function. Plant Mol. Biol. 2001, 47, 161-176. [CrossRef]

89. Majewska-Sawka, A.; Nothnagel, E.A. The Multiple Roles of Arabinogalactan Proteins in Plant Development. Plant Physiol. 2000, 122, 3-10. [CrossRef]

90. Lamport, D.T.A.; Várnai, P. Periplasmic arabinogalactan glycoproteins act as a calcium capacitor that regulates plant growth and development. New Phytol. 2012, 197, 58-64. [CrossRef] [PubMed] 
91. Offler, C.E.; Patrick, J.W. Transfer cells: What regulates the development of their intricate wall labyrinths? New Phytol. 2020, 228, 427-444. [CrossRef]

92. Seifert, G.J.; Roberts, K. The Biology of Arabinogalactan Proteins. Annu. Rev. Plant Biol. 2007, 58, 137-161. [CrossRef]

93. Lamport, D.T.A.; Kieliszewski, M.J.; Showalter, A.M. Salt stress upregulates periplasmic arabinogalactan proteins: Using salt stress to analyse AGP function*. New Phytol. 2005, 169, 479-492. [CrossRef]

94. Kobayashi, Y.; Motose, H.; Iwamoto, K.; Fukuda, H. Expression and Genome-Wide Analysis of the Xylogen-Type Gene Family. Plant Cell Physiol. 2011, 52, 1095-1106. [CrossRef] [PubMed]

95. Kremer, C.; Pettolino, F.; Bacic, A.; Drinnan, A. Distribution of cell wall components in Sphagnum hyaline cells and in liverwort and hornwort elaters. Planta 2004, 219, 1023-1035. [CrossRef]

96. Shibaya, T.; Kaneko, Y.; Sugawara, Y. Involvement of arabinogalactan proteins in protonemata development from cultured cells ofMarchantia polymorpha. Physiol. Plant. 2005, 124, 504-514. [CrossRef]

97. Shibaya, T.; Sugawara, Y. Involvement of arabinogalactan proteins in the regeneration process of cultured protoplasts of Marchantia polymorpha. Physiol. Plant. 2007, 130, 271-279. [CrossRef]

98. Shibaya, T.; Sugawara, Y. Induction of multinucleation by $\beta$-glucosyl Yariv reagent in regenerated cells from Marchantia polymorpha protoplasts and involvement of arabinogalactan proteins in cell plate formation. Planta 2009, 230, 581-588. [CrossRef]

99. Lopez-Swalls, R.A. The Special Walls around Gametes in Ceratopteris richardii and Aulacomnium palustre: Using ImmunocytoChemistry to Expose Structure, Function, and Development. Ph.D. Thesis, Southern Illinois University at Carbondale, Carbondale, IL, USA, 2016.

100. Dahiya, P.; Brewin, N.J. Immunogold localization of callose and other cell wall components in pea nodule transfer cells. Protoplasma 2000, 214, 210-218. [CrossRef]

101. Shimamura, M. Marchantia polymorpha: Taxonomy, Phylogeny and Morphology of a Model System. Plant Cell Physiol. 2015, 57, 230-256. [CrossRef] [PubMed]

102. Roberts, A.W.; Roberts, E.M.; Haigler, C.H. Moss cell walls: Structure and biosynthesis. Front. Plant Sci. $2012,3,166-173$. [CrossRef] [PubMed]

103. Gunning, B.E. Transfer cells and their roles in transport of solutes in plants. Sci. Prog. 1977, 539-568.

104. Pate, J.S.; Gunning, B.E.S. Transfer cells. Annu. Rev. Plant. Physiol. 1972, 23, 173-196. [CrossRef]

105. Offler, C.E.; McCurdy, D.W.; Patrick, J.W.; Talbot, M.J. Transfer cells: Cells Specialized for a Special Purpose. Annu. Rev. Plant Biol. 2003, 54, 431-454. [CrossRef] 